\title{
Medicinal and Nutritional Importance of C. decidua (Forssk.) Edgew. (Capparaceae): A Review
}

\author{
Sadia Chishty ${ }^{1}$, Monika ${ }^{2}$ \\ University of Rajasthan, Jaipur, Rajasthan 302004, India
}

\begin{abstract}
C. decidua, (Kair) is a densely branching shrub or small tree found growing naturally in arid and semi-arid areas of India. In Rajasthan, it occurs both on sandy and gravelly soils covered with sand dunes. C. decidua, climbing up to 6 meters in height, is widely used in traditional medicinal system of India. According to the Unani system of medicine the plant has been used as a carminative, tonic, emmenagogue, aphrodisiac, alexipharmic; improves the appetite; good for rheumatism, lumbago, hiccough, cough and asthma. Medicinally, young roots of the plants are applied to cure boils and swelling, the bark is said to be useful in asthma. The plant and fruit of C. decidua also have high nutritional value. It is also known as a rich source of alkaloids, phenols, sterols and glycosides. C. decidua (Kair) has proven to be an economically important plant in Rajasthan and elsewhere. It provides varied food and medicinal uses. The high nutritional value and traditional food and folk medicinal uses of C. deciduas is well known, it is essential to summarize a comprehensive review on related aspects of $C$. decidua plant. Therefore, the present review manuscript focuses on the detailed profile of valuable nutrients and biochemical compounds as well as medicinal health functions. An effort is made to review various studies on $C$. decidua to assess its nutritional as well as medicinal importance. Furthermore scientific validation for previous investigations is still required.
\end{abstract}

Keyword: C. deciduas, Kair, pharmacological, nutritional value, medicine, Fruits, arid and semi-arid

\section{Introduction:}

There are thousands of medicinal plants used in various traditional systems existing in India, which possess enormous potential of offering direct therapeutic effect individually or in combination. Medicinal plants have also become a growing part of modern medicine. More than $70 \%$ of the drugs listed in Ayurvedic and traditional literatures like Charaka Samhita' and Sushruta Samhita' are of herbal origin [1].

The Greek name kapparis is from the Persian kabar, -aper". Pickled capers have been used as a condiment for over 2000 years [2]. The fruit is a small many-seeded ovoid or subglobulous, slightly mucronate pink berry of the size and shape of a cherry, becoming blackish when dry and eaten by birds [3]. The plant is a large, climbing, thorny shrub, densely branched, spinous shrub or tree, up to 6 meters in height (rarely 10 meters), with a clear bole of 2.4 meters. Tender branches with waxy bloom; bark grey, rough and corky, covered with straight or recurved, 3-7 mm long, paired thorns; leaves on young branches, caduceus, linear, 1$2 \mathrm{~cm}$ long, apex short, stiff, pale mucro like pickle, petioles very short, stipular thorns long, sharp, straight orange yellow [4]. Caper buds are both wild-collected and cultivated; plants grown in cultivation tend to be spineless [5].

\section{Methodology}

An extensive bibliographical search was conducted using the following keywords: C. deciduas; Kair; traditional knowledge; pharmacological; nutritional value; medicinal characteristics of Capparis. The articles that covered pharmacological; nutritional value and medicinal characteristics were analyzed and the summary of the $C$. decidua has been elicited under various sections.

\section{Occurrence and Distribution}

It is of a common occurrence in dry places in Sind, Baluchistan, Western Rajputana, Deccan Peninsula, Egypt, Socotra, Arabia, Tropical Africa, Central India, Punjab, Gujarat, Tinnevelly and Pakistan. On most occasions C. decidua is found to be growing with Zizyphus mauritiana [6]; [7]. C. decidua or Kair is an indigenous medicinal plant of India having large biodiversity in different north-western states of India [8]. The plant usually grows in dry, exposed habitat, often on foothills, in wastelands. It is found in the deserts, especially of Rajputana, Punjab and Sind, [9] southwards to Karnataka and Tamil Nadu, [10] growing wild in Western Ghats, Rajasthan and Gujarat [5]. As an estimate, C. decidua is distributed over $3450 \mathrm{~km}^{2}$ plains in Nagaur, Bikaner and Jodhpur districts of Rajasthan with an estimated annual production of 7000 tonnes of fruits [3]. It can be found at the altitude range from 300-1 200m with mean annual rainfall of $100-750 \mathrm{~mm}$ and mean annual temperature of $25-41^{\circ} \mathrm{C}$. It has been found to be one of the best species for afforestation, reforestation and shelter belts to check the movement of sand in the Thar Desert, India [11]. Plant area is day by day shrinking to some isolated patches in the Thar Desert of Rajasthan. Quick conservation of biodiversity is urgently required to protect important plant species like C. decidua [12]. It is extremely drought resistant and tolerates some frost, resulting in an interesting plant because of its excellent adaptation to arid conditions. It can also tolerate fire and termites.

\section{Traditional Uses}

Plant has its wider utility in traditional folk medicine and is used as ailments to relieve variety of pains or aches such as toothache, cough and asthma heal. All studies indicated that the plant have significant pharmacological activities like hypercholesterolemia, anti-inflammatory and analgesic, antidiabetic, anti-microbial, anti-plaque, anti-hypertensive, anti- 


\section{International Journal of Science and Research (IJSR) \\ ISSN (Online): 2319-7064 \\ Index Copernicus Value (2013): 6.14 | Impact Factor (2014): 5.611}

helmintic activities. The compositional studies indicated $C$. decidua seeds as rich sources of all three major food components, i.e., carbohydrates, lipids and proteins. The plant and its parts are widely used by traditional healers and tribal people for curing variety of ailments. The medicinal uses of $C$. decidua are also mentioned in ancient books [13]. Powder or infusion of root bark is used in gout, rheumatism, cough, dropsy, palsy, asthma, intestinal worms and intermittent fever. The powder is applied externally on malignant ulcer [14]; [15]. A paste of coal obtained after burning the wood is applied to muscular injuries [16]. The flowers yield a steam volatile sulphur compound (0.4\%), which is active against several microorganisms [17]. Various preparations of $C$. decidua are powder and infusion of rootbark (1 in 10), dose: $1 / 2$ - 1 ounce, juice of plant [9] powder of Leaves \& root- 50-125 mg [10].

The top shoots and young leaves are made into a powder and used in blister; they are also used in boils, eruptions and swellings and as an antidote to poison. They are very efficacious in relieving toothache when chewed, [4] a decoction of ground stems and leaves is used for pyorrhea [17]. Infusion of plant is used externally for eruptions, boils, joint diseases and internally in cough and as an antidote in case of poisoning. Juice of fresh plant is used to kill worms in ear. It is also considered as a good substitute of senega [18]; [19].

In Pakistan, powder of tender branches is mixed with wheat flour and fed to animals to relieve pain [20]. The green berries and flower buds of $C$. decidua are edible and commonly pickled or used in preparation of vegetable and curry due to the folkloric belief that they have hypoglycemic effect in diabetes [18]; [20]. It is given in phthisis, heart diseases and scurvy. In Rajputana, the plant is a wholesome fodder for camels. Juice of fresh plant is dropped into the ear to kill worms [9]. Root powder is taken with water in liver problems [21]. The root bark extract is given twice a day for 3 days in the treatment of haemorrhoids [22].

Crushed bark of the plant is applied as poultice for treatment of wounds [20]. Roots are considered to be sudorific, thermogenic, expectorant, carminative, digestive, stimulant, antibacterial, aphrodisiac, anodyne, anthelmintic and useful in arthritis, dyspepsia, constipation, lumbago, odontalgia, amenorrhoea and dysmenorrhoea [23].

The plant is used for its medicinal value in diabetes, rheumatism, hypertension and various stomach problems. Wood being very strong and durable is used to make the foundations around the wells and as fire wood [24]. Flower buds are eaten to relieve stomach ache; root paste is applied on scorpion bite; powdered coal from stem is taken during fractured bone [25]. The stem bark decoction $(10-15 \mathrm{ml})$ is administered twice a day in asthma and other respiratory disorders [26].

In folk medicine, mixture of equal quantity of fruit powder and sugar is prescribed in rheumatism. They are given in diarrhoea in cattle and goats [20]. No systematic information is available for $C$. decidua nutritional value. Immediate domestication is necessary to preserve the species and put it to economic use. Limited work on $C$. decidua is available for its diversification through chemical/nutritional and molecular parameters which are important in presenting its nutritional value and diversity level [12].

\section{Phytochemistry}

Various phytoconstituents have been identified and isolated from different parts of $C$. decidua which includes alkaloids, glycosides, terpenoids, sterols, flavanoids, phenols and fatty acids. The root of $C$. decidua is found to contain sitosterol and a spermidine alkaloid, isocodonocarpine [27] [28]. It contains npentacosane, n-triacontane, n-triacontanol, 2carboxy-1, 1-dimethylpyrrolodine, 6-(1- hydroxy-non-3enyl) tetrahydropyran-2-one, $§$-sitosterol, ß-carotene, ascorbic acid, proteins, total carbohydrates, calcium, potassium, phosphorus, zinc, iron, manganese, glucosinolates. The roots contain the indole bases capparin, capparilin and capparinin [29].

The fruit extract produced significant hypocholesterolemic effect which appeared to be due to increase faecal excretion of cholesterol and bile acids which is attributed to its hemi cellulose content. The extract of defatted fruit inhibited the development of atheroma and prevented the accumulation of cholesterol and triglyceride in liver and aorta of rabbits. It reduced oxidative stress in diabetes. The extract of the fruit produced antibacterial and antifungal activities. The extract of fruit pulp, seeds, and alkaloid isolated from the extract demonstrated anthelmintic activity and affected bowel movement [30].

Various biochemical compounds, alkaloids, phenols, sterols or glycosides present in $C$. decidua sp. might be medicinally important and/or nutritionally valuable. The flowers, fruits, [32] [33] stem [34] and seeds contains n-pentacosane and ntriacontane [35]. Phytochemical screening of $C$. decidua revealed high contents of isothiocyanate glucoside, glucocapparin, stachydrine, $n$-triacontane, $\beta$-carotene and $\beta$ sitosterol. There is presence of n-triacontanol, n-pentacosane and phthalic acid [30] [17].

Table 1: Nutritional Value of Plant and Fruit

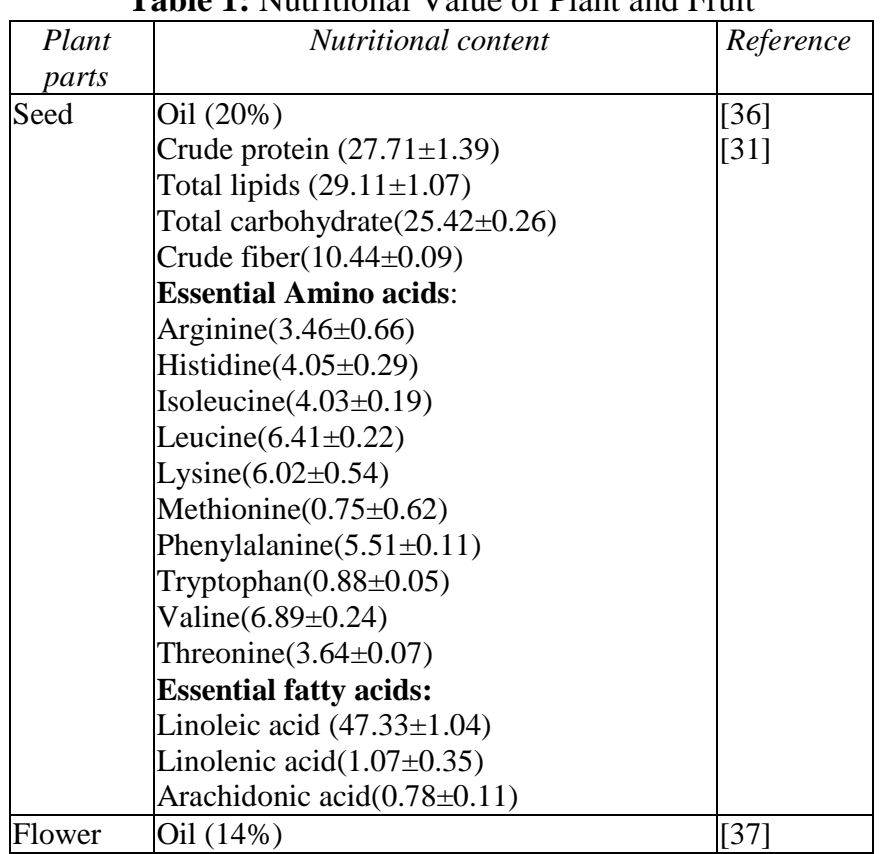


International Journal of Science and Research (IJSR)

ISSN (Online): 2319-7064

Index Copernicus Value (2013): 6.14 | Impact Factor (2014): 5.611

\begin{tabular}{|c|c|c|}
\hline & \begin{tabular}{|l|} 
Sugar $(1.7 \%)$ \\
Protein(8.06\%
\end{tabular} & \\
\hline \multirow{10}{*}{$\begin{array}{l}\text { Ripened } \\
\text { Fruit }\end{array}$} & Carbohydrate (71\%) & \multirow[t]{10}{*}[38]{} \\
\hline & Protein (15-18\%) & \\
\hline & Fat (5\%) & \\
\hline & Crude Fiber (1\%) & \\
\hline & Са (20\%) & \\
\hline & P (360\%) & \\
\hline & Zn (4\%) & \\
\hline & Fe (6\%) & \\
\hline & Mn (2\%) & \\
\hline & $\beta$-Carotene $(14 \%)$ & \\
\hline \multirow{22}{*}{$\begin{array}{l}\text { Ripened } \\
\text { fruit dried }\end{array}$} & Crude protein (14.94 \%) & \multirow[t]{14}{*}[3]{} \\
\hline & Total carbohydrate (73.48 \%) & \\
\hline & Soluble carbohydrate (18.03 \%) & \\
\hline & Moisture (69.66\%) & \\
\hline & Phosphorus (219.05 mg/100g) & \\
\hline & Magnesium (49.16 mg/100g) & \\
\hline & Iron $(4.64 \mathrm{mg} / 100 \mathrm{~g})$ & \\
\hline & Zinc (0.31 mg/100g) & \\
\hline & Copper (1.94 mg/100g) & \\
\hline & Sodium (160.64 mg/100g) & \\
\hline & Calcium (3.24\%) & \\
\hline & Starch $(15.28 \%)$ & \\
\hline & Crude fiber (10.94 \%) & \\
\hline & Crude fat (5.38 \%) & \\
\hline & Moisture content 65.5\% & {$[39]$} \\
\hline & Carbohydrates $8.5 \mathrm{mg} / 100 \mathrm{mg}$ & \\
\hline & Proteins $8.4 \mathrm{mg} / 100 \mathrm{mg}$ & \\
\hline & Phenolic compounds $0.8 \mathrm{mg} / 100 \mathrm{mg}$ & \\
\hline & Alkaloids $1.5 \mathrm{mg} / 100 \mathrm{mg}$ & \\
\hline & Iron $3.972 \mathrm{mg} / \mathrm{kg}$ & \\
\hline & Copper 0.162 mg/Kg & \\
\hline & Manganese $0.06 \mathrm{mg} / \mathrm{kg}$ & \\
\hline
\end{tabular}

\section{Biological activities /Medicinal Potential of C. decidua}

\subsection{Sedative and anticonvulsant effects}

An alcoholic extract of aerial parts of $C$. decidua, including flowers and fruits, was screened for central nervous system (CNS) activity using conventional behavioural animal models. In the pentylenetetrazole-induced seizures test the C. decidua extract dose-dependently decreased $(P<0.05)$ the number of animals with convulsions and increased convulsion latency $(P<0.001)$; none of the animals treated with extract died in the test. $C$. decidua extract decreased the duration of tonic hind leg extension in maximal electroshock-induced seizures $(P<0.001)$ when compared with control. C. decidua has CNS depressant and anticonvulsant activities [40].

\subsection{Anti-inflammatory and analgesic activity}

The in vitro anti-inflammatory Activity observed in their study support the utilization of the plants in traditional medicine as crude anti-inflammatory agents [41]. Ethanolic extract of aerial parts exhibited anti-inflammatory and analgesic activity. Isocodonocarpine was found to be responsible for anti-inflammatory activity and anti asthmatic activity [42]. $\beta$-Sitosterol isolated from the root bark has been examined for possible anti-inflammatory activity in acute and chronic inflammatory models. $\beta$-sitosterol exerted statistically significant and dose-dependent antiinflammatory activity in carageenan-induced rat paw oedema, which was similar to Indomethacin. Topical application of $\beta$-Sitosterol significantly inhibited ear inflammation induced by multiple applications of tetradecanoylphorbol-13-acetate in mice. $\beta$-Sitosterol significantly inhibited adjuvant-induced rat paw oedema [43]. The results suggested that $\beta$-Sitosterol exerts antiinflammatory activity, at least in part through inhibition of cyclo-oxygenase and 5-lipoxygenase pathways [44].

Table 2: Pharmaceutical/Therapeutic Potential of Different Caper Parts

\begin{tabular}{|c|c|c|}
\hline Part & Diseases & References \\
\hline Stem barks & $\begin{array}{l}\text { Toothache, cough, asthma, } \\
\text { intermittent fever, rheumatism, } \\
\text { inflammation, kidney infection, } \\
\text { and treatment of wounds as } \\
\text { poultice }\end{array}$ & $\begin{array}{c}{[45] ;[46] ;[20] ;} \\
{[47]}\end{array}$ \\
\hline $\begin{array}{l}\text { Fruits and } \\
\text { flowers }\end{array}$ & $\begin{array}{c}\text { Diabetes, respiratory diseases, skin, } \\
\text { anthelmintic, diuretic, cardiac and } \\
\text { biliousness diseases, anti-diabetic } \\
\text { and eyesight smoothing properties, } \\
\text { laxative potential, atherosclerosis, } \\
\text { and plaque }\end{array}$ & $\begin{array}{l}{[20] ;[48] ;[49]} \\
{[50] ;[51] ;[52] ;} \\
\quad[42]\end{array}$ \\
\hline Roots & $\begin{array}{c}\text { Digestive diseases, stimulant, } \\
\text { anodyne, sudorific, constipation, } \\
\text { lumbago, odontalgia, and } \\
\text { amenorrehoea }\end{array}$ & {$[52]$} \\
\hline Root bark & $\begin{array}{l}\text { Gout, cough, flu, dropsy, palsy, } \\
\text { asthma, and intestinal worms }\end{array}$ & [53] \\
\hline Leaves & Toothache, swellings, and blisters & [51] \\
\hline Shoot & Hypercholesterolemia & [54] \\
\hline
\end{tabular}

\section{Cited from Gull et al. [69]}

\subsection{Anti-diabetic activity}

According to Grover et al. [55] C. decidua may have potential use as an anti-diabetic agent and in lowering oxidative stress in diabetes. Fruits possess anti-diabetic activity. C. decidua powder has hypo-glycaemic activity, decreases lipid peroxidation and alters free radical scavenging enzymes such as superoxide dismutase and catalase in erythrocytes, liver, kidney and heart in aged alloxan induced diabetic rats. C. decidua powder is used against alloxan induced oxidative stress and diabetes in rats [55]. The aqueous \& ethanolic extracts were orally administered to diabetic rats at 250 and $500 \mathrm{Mg} / \mathrm{kg}$ doses daily for 21 days to determine anti-diabetic activity. Purohit and Vyas [57] reported that aqueous and ethanolic extract of stem has significant hypo-glycaemic and anti-diabetic potential [57].

Alloxan-induced diabetic rats were treated with insulin (i.p.) or with $C$. decidua powder as a hypoglycaemic agent mixed with diet. The effect was assessed on lipid peroxidation and the antioxidant defense system in rat tissues. The increased levels of blood glucose in diabetes produce superoxide anions and hydroxyl radicals in the presence of transition metal ions which cause oxidative damage to cell membranes. The heart tissue showed an increased lipid peroxidation in diabetic rats while no significant change was observed in the liver and kidney. The treatment with $C$. deciduas lowered lipid peroxidation in these tissues even more effectively than insulin-treated rats. The superoxide dismutase activity increased in the heart and kidneys in the diabetic group of rats probably to increase dismutation of

\section{Volume 5 Issue 2, February 2016}




\section{International Journal of Science and Research (IJSR) \\ ISSN (Online): 2319-7064 \\ Index Copernicus Value (2013): 6.14 | Impact Factor (2014): 5.611}

superoxide anions. However, treatment with $C$. deciduas decreased superoxide activity in the liver and kidney and was comparable to control rats. The increase in Sedependent glutathione peroxidase and CAT activity with $C$. decidua treatment may lower $\mathrm{H}_{2} \mathrm{O}_{2}$ toxicity and reduce oxidative stress in diabetes. Glutathione content in the heart and kidney and glutathione reductase activity in all the tissues studied increased in diabetic rats while treatment with insulin lowered GSH content and glutathione reductase activity in these tissues. The treatment with $C$. decidua also decreased glutathione reductase activity in the kidney and heart which resulted in the decrease in GSH content in these tissues. The changes such as the increase in kidney and heart superoxide dismutase may be an adaptive response in order to neutralize superoxide anions. The increase in Glutathione content and glutathione reductase activity in the tissue are in response to neutralize superoxide anions and to counteract oxidative stress in diabetes. The data indicate that $C$. decidua may have potential use as an antidiabetic agent and in lowering oxidative stress in diabetes [42] [55]. Sharma et al. [58] concluded Alkaloid rich fraction showed promising results in terms of anti-diabetic activities establishing its candidacy for further purification and characterization of the individual alkaloids, in order to understand their mechanism of action. It significantly reduced total cholesterol and triglyceride content. The expression of different target genes like G6Pase, phosphoenolpyruvate carboxykinase, aldose reductase and tumour necrosis factor- $\alpha$ (TNF- $\alpha$ ) showed significant reduction [58].

\subsection{Hypo-cholesterolemic effect}

The extract of unripe fruits and shoots of $C$. decidua cause reduction in plasma triglycerides, total lipids and phospholipids; hence used as hyper-cholesterolemic. It appeared to operate through increased fecal excretion of cholesterol as well as bile acids [54].

Fasting blood samples were analyzed for total, LDL and HDL cholesterol at pre and post of experiment. Standardized C. decidua various products were used. A significant decrease in the total cholesterol (13\%) and LDL cholesterol (16\%) was seen. However, no significant change in HDL cholesterol was noticed. C. decidua supplementation may have an important role in nutritional management of hypercholesterolemia [67]; [55].

\subsection{Anti-atherosclerotic activity}

The study by Purohit and Vyas [57] demonstrated that $C$. decidua fruit extract possesses hypolipidemic and antiatherosclerotic effects. The fruit alcohol extracts of the plant $C$. decidua (Frosk). Hyperlipidemia was generated by atherodiet and cholesterol feeding to animals. Rabbits were fed $C$. decidua (500 mg/kg body weight) or pitavastatin (0.2 $\mathrm{mg} / \mathrm{kg}$ body weight) in distilled water along with standard laboratory diet and atherodiet for 60 days. C. decidua fruit extract and pitavastatin were found to lower serum cholesterol, LDL-cholesterol, triglyceride, phospholipids, and atherogenic index, but found to increase the HDL to total cholesterol ratio as compared with hyperlipidemic control group. Pitavastatin or C. decidua fruit extract treated hyperlipidemic rabbits showed a decrease in the lipid profile of liver, heart, and aorta. The plant extract feeding brought a definite regression of atheroma and hindered plaque formation in aorta as compared with the hyperlipidemic control group [57].

\subsection{Antioxidant activity}

Antidiabetic treatment with powdered fruit of $C$. decidua decreased Alloxan induced lipid peroxidation significantly in erythrocytes, kidney and heart [42]. Treatment with $C$. decidua lowers alloxan induced lipid peroxidation and alters superoxide dismutase and catalase enzymes to reduce oxidative stress. Anti-oxidant and $\beta$-cell regeneration effect of stem extract in streptozotocin-induced diabetic rat have been evaluated. Methanolic extract and active fraction from stem part significantly reduced blood glucose levels in diabetic rats. Extract exerted rapid protective effects against lipid peroxidation by scavenging of free radicals thereby reducing risk of diabetic complications [59].

\subsection{Hypo-lipidemic activity}

Three different alcoholic extracts obtained from bark, flower and fruit have been shown to have hypo-lipidaemic activities in rats. The alcoholic extracts restored the elevated levels of serum lipids to normal and showed significant decrease in levels of total cholesterol, triglycerides, LDL and VLDL cholesterol [28]. Alcoholic extract of husk of fruits, seeds and flowers were demonstrated to be antibacterial [60].

In Purohit and Vyas [61] experiment high fat diet caused significant (8-fold) increase in serum total cholesterol in rabbits. Administration of $C$. decidua fruit extracts $(50 \%$ ethanolic) dosage of $500 \mathrm{mg} / \mathrm{kg}$ body weight which significantly reduced serum total cholesterol (61\%), LDL cholesterol (71\%), triglycerides (32\%) and phospholipids (25\%). Similarly C. decidua shoot extract lowered serum total cholesterol (48\%), LDL cholesterol (57\%), triglycerides (38\%) and phospholipids (36\%).The cholesterol content of aorta was decreased by 44 and $28 \%$ in fruit and shoot extract treatment respectively. The results confirmed the hypolipidemic potential of $C$. decidua fruit and shoot [61]. Significant reductions in plasma triglycerides, total lipids and phospholipids concentration were noticed [54]. 50\% ethanolic fruit extract showed hypolipidemic effect in cholesterol fed rabbits, by significant reduction of serum cholesterol, serum triglycerides and LDL and increase HDL ratio and excretion of cholesterol [62].

\subsection{Antihypertensive Activity}

In anaesthetized rats, an ethanolic extract so obtained of $C$. decidua caused a fall in systolic, diastolic and mean blood pressure in a dose dependent manner. The administration of $1,3,10 \mathrm{mg} / \mathrm{kg}$ doses of the extract manifested decreases of $20 \%, 30 \%$ and $47 \%$ in mean arterial blood pressure respectively. It was then observed that hypotensive effect was short as far as onset of duration ultimately returning to normal within 2 min [41]. On the whole it can be logically deduced that the alcoholic extract of $C$. decidua produces non specific relaxant effects on cardiac and smooth muscle tissue and that this action is probably responsible for its hypotensive and bradycardiac effects [29].

\section{Volume 5 Issue 2, February 2016}




\section{International Journal of Science and Research (IJSR) \\ ISSN (Online): 2319-7064}

Index Copernicus Value (2013): 6.14 | Impact Factor (2014): 5.611

\subsection{Anti bacterial activity}

C. decidua extracts are also rich in antioxidant compounds, phenolics, flavonoids, rutin, tocopherols, carotenoids and vitamin C [31]; [32] [63]. The inhibited growth of E. coli and $S$. aureus can be correlated with flavonoid compounds in $C$. decidua extracts [64]. Such studies show that the extracts rich in phenolic acids and flavonoids, exhibit better antimicrobial potential [65];[66].

Aqueous extract of the plant exhibits anthelmintic activity; seeds contain antibacterial principles-glucocapparin; isothiocyanate aglycone of glucocapparin [10]. Flavonoid fractions obtained from different parts of $C$. decidua (root, stem and flowers) have been studied for their antimicrobial activity using disc diffusion assay, against two Gram negative bacteria (Escherichia coli and Proteus mirabilis), one Gram positive bacteria (Staphylococcus aureus) and a fungi (Candida albicans). The plant exhibited broad spectrum activity [64]. Seeds have been shown to possess antibacterial activity against Vibrio cholera, Vibrio ettor and Vibrio inaba [68]. Gull et al. [69] used selected parts of $C$. deciduas and evaluated against four Gram positive and negative bacteria. The growth of all four bacteria was significantly inhibited by the application of $C$. decidua extracts in comparison with synthetic drugs i.e., amoxycillin and ciprofloxacin. Aqueous methanolic extracts were found to be more effective in comparison with ethanol and acetone extracts against all bacteria but extracts of different parts exhibited variable efficacy in limiting bacterial development.

C. decidua stem bark aqueous methanolic extract effectively inhibited Bacillus subtilis and $P$. multocida growth, while other bacteria showed some resistance. Aqueous methanolic extract of $C$. deciduas shoot has inhibiting potential against Bacillus subtilis and Aspergillus niger[70].

Upadhyay et al [71] reported the antimicrobial potential of absolute and aqueous methanol extracts of $C$. decidua against Klebsiella pneumoniae, E. coli, Micrococcus luteus, Streptococcus pneumoniae, S. aureus, Bacillus cereus and Lactobacilus acidophilus.

Table 3: Antimicrobial Activity of Different Parts/Extracts of Capparis Species Against Microorganisms.

\begin{tabular}{|c|c|c|}
\hline Plants/parts & Microorganisms & References \\
\hline $\begin{array}{l}\text { Ethanolic } \\
\text { extract of } C \text {. } \\
\text { decidua root } \\
\text { bark }\end{array}$ & $\begin{array}{c}\text { Pseudomonas aeruginosa, } \\
\text { Staphylococcus aureus, and } \\
\text { Escherichia coli }\end{array}$ & {$[72]$} \\
\hline $\begin{array}{c}\text { Aqueous, } \\
\text { chloroform, } \\
\text { acetone, } \\
\text { methanol } \\
\text { and ether } \\
\text { extracts of } \\
\text { C. deciduas }\end{array}$ & $\begin{array}{c}\text { Klebsiella pneumoniae, } \\
\text { Escherichia coli, Micrococcus } \\
\text { luteus, Streptococcus } \\
\text { pneumoniae, Staphylococcus } \\
\text { aureus, Bacillus cereus, } \\
\text { Proteus mirabilis, } \\
\text { Lactobacilus acidophilus, } \\
\text { and Candida albicans } \\
\text { (Fungus) }\end{array}$ & $\begin{array}{c}\text { [72];[73]; } \\
{[50]}\end{array}$ \\
\hline $\begin{array}{l}\text { C. decidua } \\
\text { seeds }\end{array}$ & $\begin{array}{c}\text { Vibrio cholera, V. ogava, V.inaba, } \\
\text { V. ettor, and V. eltor }\end{array}$ & $\begin{array}{c}{[68] ;[74] ;} \\
{[75]}\end{array}$ \\
\hline
\end{tabular}

Cited from Gull et al [69]

\section{Conclusion}

C. decidua (Kair) has proven to be an economically important plant in Rajasthan and elsewhere. It provides varied food and medicinal uses. C. decidua is a rich and valuable source and it can be used as a potential dietary source. The present review summarizes some important pharmacological studies on $C$. decidua. It has wider availability and is inexpensive source of bioactive components. Besides, its usefulness in numerous ailments it is also mentioned in Ayurveda and proven scientific investigation of its therapeutic worth. Various chemical compounds have been identified and isolated from different parts of $C$. decidua, but no research report on the contents of anti-nutritional factors or harmful chemical compounds/constituents in extracts of $C$. decidua is carried. Various health supplements could be prepared to utilize its potential. Therefore furthermore scientific validation for previous and new investigations for anti-nutritional factors is still required.

\section{References}

[1] Shrishailappa B, Desai V B and Suresh B, Ethnopharmacolgoy, its relevance and need in India", Eastern Pharma, Volume: 64 pp. 35-38, 2010.

[2] Bown D Encyclopaedia of Herbs", The Royal Horticulture Society, Dorling Kindersley Ltd, Volume: 1, pp.152, 2008.

[3] Kumar S, Sharma R, Kumar V, Govind K, Vyas and Rathore A, Eombining molecular-marker and chemical analysis of C. decidua (Capparaceae) in the Thar Desert of Western Rajasthan (India)", Rev. Biol. Trop. (Int. J. Trop. Biol. ISSN-0034-7744), Volume: 61, issue:1, pp. 311-320, 2013.

[4] Kirtikar K R and Basu B, -Idian Medicinal Plants", International Book Distributers, Dehradun, Volume: 2, Issue: 1, pp. 195-199, 2008.

[5] Bown D Encyclopaedia of Herbs", The Royal Horticulture Society, Dorling Kindersley Ltd, Volume: 1, pp.187, 2008.

[6] Chavan A R and Oza G M, The Flora of Pavagadh", The Maharaja Sayajirao University of Baroda, Botanical Memoirs: No. 1, MSU of Baroda: 14, 1966.

[7] Kirtikar K R and Basu B D, Indian Medicinal Plants" Vol. I, $2^{\text {nd }}$ Ed., M/S Bishen Singh Mahendra Pal, Delhi $197,1933$.

[8] Troup R S, The Silviculture of Indian Trees", Printed in India at the FRI Press, Forest Research Institute and Colleges, Dehradun and Published by the Controller of Publications, Delhi, 1975.

[9] Nadkarni K M, Indian Materia Medica" Bombay Popular Prakashan, volume: 3, pp. 265, 2000.

[10] Khare C P," Indian medicinal plants", Springer India Pvt. Ltd 117, 2008.

[11] Pandey A N and Rokad M V, Sand Dune Stabilization: an investigation in the Thar Desert", Ind J Arid Environ, volume: 22, pp. 287-292, 1992.

[12]Kumar S, Ali S, Singh G, Saxena S N, Sharma S, Mahala H R, Sharma T B and Sharma R, Association and variation among some important nutritional traits of ker (C. decidua decidua)",Annals Arid Zone, volume: 50, pp.1-6, 2011. 


\section{International Journal of Science and Research (IJSR) \\ ISSN (Online): 2319-7064}

Index Copernicus Value (2013): 6.14 | Impact Factor (2014): 5.611

[13] Verma P D, Dangar R D., Shah K N, Gandhi D M and Suhagia S N, Pharmacognostical Potential of $C$. decidua deciduas Edgew", Journal of Applied Pharmaceutical Science, volume :01, issue:10, pp. 0611, 2011.

[14] Chunekar K C and Pandey G S. Bhavprakash nighantu. Chaukhambha Bharti Academy, 8th Ed., Gokulbhavan, Varanasi: 546, 1999.

[15] Anonymous, The Wealth of India, Raw Materials. Vol. II, CSIR, Delhi 67, 1950.

[16]Gupta A K and Shama M, Reviews on Indian Medicinal Plants", Medicinal Plant Unit, ICMR, New Delhi 5:389, 2007.

[17] Anonymous, The Wealth of India: A Dictionary of Indian Raw Materials \& Industrial products", First Supplementary Series (Raw materials), National Institute of Science Communication and Information Resources, CSIR, New Delhi, volume: 1, pp. 211-212, 2007.

[18] Nadkarni K M, Indian Materia Medica. Part-I, 3rd Ed. Vegetable Kingdom: 265, 1954.

[19] Shastri G M and Bhavprakash, Part-I, 1st Ed., Sastu Sahitya Vardhak karyalaya, Mumbai 368, 1957.

[20] Marwat S K, Fazal U R, Usman K, Khakwani A A, Ghulam S, Anwar N, Sadiq M and Khan S J, MedicoEthnobotanical Studies of Edible Wild Fruit Plant Species from the Flora of North Western Pakistan, D.I. Khan District", J Med Pl Res, volume: 5, issue: 16, pp. 3679-3686, 2011.

[21] Shekhawat D and Batra A, "Household remedies of Keshavraipatan tehsil in Bundi, Indian journal of traditional knowledge", volume: 5, issue: 3, pp. 362367, 2006.

[22] Jadeja B A, Odedra N K and Odedra K R, Herbal remedies used for haemorrhoids by tribals of Saurashtra, Gujarat", Indian journal of traditional knowledge, volume: 5, issue: 3, pp.348-352, 2006.

[23] Longman O, Vaidyaratnam P S and Varier, Indian Medicinal Plants, a compendium of 500 species", Volume: 1, pp.368, 1994.

[24] Goyal M and Sharma S K, Traditional wisdom and value addition prospects of arid foods of desert region of North West India", Indian journal of traditional knowledge, volume: 8, issue: 4, pp. 581-585, 2009.

[25] Meena K L and Yadav B L, Some Ethnomedicinal Plants of Southern Rajasthan, Indian journal of traditional knowledge", volume: 9, issue: 1, pp. 169172, 2010.

[26] Patil G G, Mali P Y and Bhadane V B, Natural Product Radiance, volume: 7, issue: 4, pp. 354-358, 2006.

[27] Rathee S, Mogla OP, Rathee $P$ and Rathee D, Quantification of $\beta$ - Sitosterol using HPTLC from $C$. decidua deciduas", Der Pharma Chemica, volume: 2, issue:4, pp. 86-92, 2010.

[28] Chahlia N, Effect of C. decidua on hypolipidaemic activity in rats", J. Med. Plants. Res, volume: 3, issue: 6, pp. 481-484, 2009.

[29] Singh P, Mishra G, Sangeeta, Srivastava S , Jha K and Khosa R L, Traditional uses, phytochemistry and pharmacological properties of $C$. decidua: An Overview", Der Pharmacia Lettre, volume: 3, issue:2, pp.71-82, .2011.
[30]Gupta A K, Tondon N and Sharma M, Quality Standards of Indian Medicinal Plants, Medicinal Plants Unit", Published by Indian Council of Medical Research, New Delhi, volume: 3, pp. 99-105, 2008.

[31]Zia-ul-Haq M, Cavar S, Qayum M, Imran I and Feo de V, Eompositional Studies: Antioxidant and Antidiabetic Activities of C. decidua (Forsk.) Edgew", Int. J. Mol. Sci,volume: 12, pp. 8846-8861, 2011.

[32] Gaind K N and Juneja T R, Res Bull Punjab Univ. Sc, volume: 21, pp.67-71, 1970.

[33] Tlili N, Nasri N, Khaldi A, Triki S and Bosch S M, Phenolic compounds, tocopherols, carotenoids and vitamin C of commercial caper", J. Food Biochem, volume:35, pp. 472-483, 2011.

[34] Upadhyay R K, Ahmad S, Tripathi R, Rohtagi L and Jain S C, Screening of antimicrobial potential of extracts and pure compounds isolated from C. decidua decidua", J. Med. Plant Res, volume:4, pp.439-445, 2010.

[35] Dahot M.U. Ehemical evaluation of the nutritive value of flowers and fruits of Capparis deciduas". J. Chem. Soc. Pak, volume:15, pp.78-81, 1993

[36] Rai S and Rai S, -il and fats in arid plants with particular reference to $C$. decidua deciduas", L.Trans. Indian Soc.Des. Technol, volume: 12, pp. 99-105, 1987.

[37] Mishra S N, Tomar P C and Lakra N, Medicinal and food value of $C$. decidua - a harsh terrain plant", Ind J Trad. Knowl, volume: 6, issue: 1, pp. 234, 2007.

[38] Chaturvedi Y and Nagar R, tevel of beta carotene and effects of processing on selected fruits and vegetables of the arid zone of India", Plant foods Human Nutr, volume: 56, pp.127-132, 2001.

[39] Ghangro I H, Ghangro A B and Channa M J, Nutritional assessment of non conventional vegetable C. decidua flower", Rawal Medical journal, pp. 40-2, 2015.

[40] Goyal M, Nagori B P , Sasmal D, Sedative and anticonvulsant effects of an alcoholic extract of Capparis deciduas",Journal of Natural Medicines,volume: 63, issue: 4, pp. 375-379, 2009.

[41]Eldeen I M S and Staden Van J, - Eyclooxygenase inhibition and antimycobacterial effects of extracts from Sudanese medicinal plants", South African Journal of Botany,volume: 74, issue: 2, pp. 225-229, 2008.

[42] Yadav P, Sarkar S and Bhatnagar D, Eipid peroxidation and antioxidant enzymes in erythrocytes and tissues in aged diabetic rats", Indian J. Exp. Biol, volume:35, pp. 389-392, 1997.

[43] Yadav P, Sarkar S and Bhatnagar D, Action of Capparis decidua against alloxan induced oxidative stress and diabetes in rat tissue", Pharmacological Research, volume: 36, issue: 3, pp. 221-228, 1997.

[44] Perianayagam J R, Sharma S K and Pillai K, Antiinflammatory potential of $\beta$-sitosterol on acute and chronic inflammation models", Rec Prog Med, pp. 22, 2008.

[45] Afsharypuor S, Jeiran K, Jazy AA, First investigation of the flavour profiles of the leaf: ripe fruit and root of Capparis spinosa var. mucronifolia from Iran", Pharm. Acta Helv, volume: 72, pp. 307-309, 1998.

[46] Ahmad V U, Ismail N, Arif S and Amber A U R, Two new $\mathrm{N}$-acetylated spermidine alkaloids from Capparis decidua”, J. Nat. Prod, volume:55, pp.1509-1512, 1992. 


\section{International Journal of Science and Research (IJSR) \\ ISSN (Online): 2319-7064 \\ Index Copernicus Value (2013): 6.14 | Impact Factor (2014): 5.611}

[47] Ozcan M, -Mineral composition of different parts of Capparis ovata Desf. var. canescens (Coss.) Heywood growing wild in Turkey",J. Med. Food, volume: 8,pp. 405-407, 2005.

[48] Nadkarni K M and Nadkarni A, Indian Materia Medica: With Ayurvedic, Unani-tibbi, Siddha, Allopathic, Homeopathic Naturopathic \& Home Remedies",3rd Ed. Popular Book Depot, 1954.

[49] Rathee S, Rathee P, Rathee D, Rathee D and Kumar $\mathrm{V}$, Phytochemical and pharmacological potential of kair (Capparis decidua)", Int. J. Phytomed, volume: 2,pp. 10-17, 2011.

[50] Sharma B and Kumar P, Extraction and pharmacological evaluation of some extracts of Tridax procumbens and Capparis decidua", Int. J. Appl. Res. Nat. Prod, volume: 1, pp.5-12, 2008.

[51] Vaidya B G, Dravyaguna Shastra. 2nd Ed., University Granthnirman Board, Gujarat State, pp. 454, 1995.

[52] Warrier P K, Nambiar V and Ramankutty C, Indian medicinal plants: a compendium of 500 specie",. Orient Blackswan, 1996.

[53] Pandey G, Chunekar K and Bhavprakash N B, Ehaukhambha Bharati Academy: Varanasi, 8th Ed. Gokulbhavan, Varanasi, India, 1998.

[54]Goyal R and Grewal R, The influence of teent (Capparis decidua) on human plasma triglycerides, total lipids and phospholipids", Nutr. Health, volume: 17, pp.71-76, 2003.

[55] Grover J K, Yadav S and Vats V, Medicinal plants of India with anti-diabetic potential", Journal of Ethno pharmacology, volume: 81, issue: 1, pp.81-100, 2002.

[56] Agarwal V and Chavan B M, A study on composition and hypolipidaemic effect of dietary fibre from some plant foods", Plant Foods Hum Nutr, volume: 38, pp. 189-197, 1988.

[57] Purohit A and Vyas K B, Antiatherosclerotic effect of Capparis deciduas fruit extract in cholesterol-fed rabbits”, Pharmaceutical Biology, volume: 44, issue: 3, pp. 172-177, 2006.

[58] Sharma B and Kumar P, Extraction and Pharmacological Evaluation of some extracts of Tridax procumbens and C. decidua", Internat J Appl Res Nat Prod, volume: 1, issue:4, pp. 5-12, 2009.

[59] Dangi K S and Mishra S N, Anti-oxidant and $\beta$-cell regeneration effect of $C$. decidua aphylla stem extract in streptozotocin-induced diabetic rat", Biol and Med, volume: 3, issue:3, pp. 82-91, 2011.

[60] Gaind K N, Juneja T R and Jain P C, Investigation on C. decidua Edgew, Antibacterial and antifungal studies", Ind J Pharmacol, volume: 3, pp. 124-125, 1969.

[61] Purohit A and Vyas K B, Hypolipidaemic efficacy of Capparis deciduas fruit and shoot extracts in cholesterol fed rabbits", Indian Journal of Experimental Biology, volume:43, issue:10, pp. 863-866, 2005.

[62] Sharma I, Gusain D, Sharma A and Dixit V P, Hypolipidemic effect of C. decidua fruit extract (50\% ethanolic) in cholesterol fed rabbits", Indian Drugs,volume: 28, issue: 9, pp. 413, 1991.

[63] Imran I, Haq MZ, Calani L, Mazzeo T and Pellegrini N, Phenolic profile and antioxidant potential of selected plants of Pakistan", J. Appl. Bot. Food Qual, volume:87, pp. 30-35, 2014.
[64] Sharma B and Kumar P, Extraction and pharmacological evaluation of some extracts of Tridaz procumbent and C. decidua", Int. J. Appl. Res. Nat. Prod, volume: 1, pp. 5-12, 2009.

[65] Sivropoulou, Kokkini S, Lanaras T and Arsenakis M, Antimicrobial activity of mint essential oils", J. Agric. Food Chem, volume: 43, pp. 2384-2388, 1995.

[66] Proestos C I, Boziaris, Nychas G J and Komaitis M, Analysis of flavonoids and phenolic acids in Greek aromatic plants: Investigation of their antioxidant capacity and antimicrobial activity", Food Chem, volume: 95, pp. 664-671, 2006.

[67] Goyal R and Grewal R, Journal Nutrition \& Food Science, volume: 40, pp. 3, 2010.

[68] Gaind K, Juneja $\mathrm{T}$ and Bhandarkar P, Volatile principle from seeds of Capparis decidua. Kinetics of in vitro antibacterial activity against Vibrio cholerae ogava, inaba, and eltor, Indian J. Pharm, volume: 34, pp.86-88, 1972.

[69]Gull T, Sultana B, Bhatti I A and Jamil A, Antibacterial potential of $C$. decidua spinosa and C. decidua extracts, Int. J. Agric. Biol, volume: 17, pp.727733, 2015.

[70] Iqbal S, Bhanger M I, Akhtar M, Anwar F, Ahmed K R and Anwer T, Antioxidant Properties of Methanolic Extracts from Leaves of Rhazya stricta", J. Med. Food, volume: 9, pp.270-275, 2006.

[71] Upadhyay R K, Rohatgi L, Chaubey M K and Jain S C, Ovipositional responses of the pulse Bruchus chinensis (Coleoptera: Bruchidae) to extracts and compounds of Capparis deciduas", Journal of Agricultural and Food Chemistry, volume: 54, issue: 26, pp.9747-9751, 2006.

[72] Mali R, Hundiwale J, Sonawane R, Patil R and Hatapakki B, Evaluation of Capparis decidua for anthelmintic and anti-microbial activities", Indian $\mathrm{J}$. Nat.Prod, volume: 20,pp. 10-13, 2004.

[73] Ravi K U, Shoeb A, Rajani T, Leena R and Subhash C J, Screening of antimicrobial potential of extracts and pure compounds isolated from Capparis decidua”, J. Med. Plants Res, volume: 4, pp. 439-445, 2010.

[74] Joseph B and Jini D, A medicinal potency of Capparis decidua - a harsh terrain plant, Res. J. Phytochem, volume: 5, pp. 1-13, 2011.

[75] Juneja T, Gaind K and Panesar A, Investigations on Capparis decidua Edgew; study of isothiocyanate glucoside. Panjab Univ, Res. Bull, volume: 21, pp. 519521, 1971. 